\title{
Relations between Man and the Environment through the Analysis of the Symbolism of the Herbs and Trees in Caribbean Literature
}

\author{
Chali Jean-Georges \\ Université des Antilles, Schoelcher, Martinique \\ Email: Chali.jean-georges@orange.fr
}

Received 19 June 2016; accepted 10 July 2016; published 13 July 2016

Copyright (C) 2016 by author and OALib.

This work is licensed under the Creative Commons Attribution International License (CC BY). http://creativecommons.org/licenses/by/4.0/

(c) $\underset{\mathrm{EY}}{\mathrm{E}}$ Open Access

\section{Abstract}

The question of representations of the forest world, trees and plants in the Caribbean literature is important in the understanding of the relationship between man and nature. This work deals with the study of literary texts which highlight this human-nature interaction serving as the writer's base to establish the legitimacy of the literary discourse. It anchors this dialogue in reality and knowledge of the world which translates the relationship between man and his environment. The data recorded during this study allow us to develop this continuum between literature, the world perception in the oral tradition and biotope observation by the endogenous populations. The writer renders the syncretic dimension that serves as the basis of literary aesthetics through writing and the popular imagination.

\section{Keywords}

Symbolic, Representations, Trees, Plants, Forest, Caribbean, Tales, Legends, Literature, Biodiversity, Human, Nature, Function, Magical-Religious, Relationship, Sacred

Subject Areas: Literature, Sociology, Human Geography

\section{Introduction}

The tales and legends of the Caribbean have always given the environment an important role to play in the form of either plants or other natural elements that make up the biodiversity of our country. In particular, since the Amerindian period, the Forest has played an important role with the remarkable function vested in trees. The literature itself gives us specific representations and suggests that some plants, leaves and trees have magical-reli-

How to cite this paper: Jean-Georges, C. (2016) Relations between Man and the Environment through the Analysis of the Symbolism of the Herbs and Trees in Caribbean Literature. Open Access Library Journal, 3: e2765. 
gious functions in principal as part of the initiating tests for example Cabouya (Table 1) or the bean leaves (Table 1) in Zobel's work Rue Cases-nègres [1]. Doesn't the relationship with nature also exhibit an original character in the Caribbean writer who turns it into a temple of poetic inspiration and devotes more attention to it just like Jean-Jacques Rousseau in his Musings attributed a creative virtue to plants? Joseph Zobel and many others find their source of inspiration here and endeavour to describe the nature, plants, trees as inseparable elements of the poetic universe to the point of granting the latter a dreamlike dimension and having with it a "Relationship" that would fall under the scope of the sacred.

There is a very close relationship between man and the natural environment in the Caribbean. The contact with the biotope leads us to believe that since ancient times, man has always turned to nature to question it and especially to determine the conditions of his own existence. For this purpose, the alien creature in this environment had to observe all the elements that make up its essence and are able to deliver the deepest secrets of a fauna and flora which are often ruthless. Through these actions we will understand that everything is connected to the plant world and men whether endogenous or exogenous have rapidly become nature's allies in the end creating a true link in what is called an anthropo-ecosystem.

The first elements of this dynamic and empirical approach were the tales and legends from the cultural and anthropological group polysynthetism [2] linked to the various conquests of territories where the creole culture bears a relevant testimony. Is it not true that many fantastic stories, Creole songs, literary works are the expression of a popular form or a way of presenting the relationship we have with the real world? Nature seems to govern the daily lives of these women and men who derive life lessons from observing it and adopt a certain philosophy with regard to natural life and the behaviour of the living things which are the plants and trees. This is why most of the stories take these natural elements out of the reification to give them a soul and interpret the world.

Man understood that nature has a dual nature since it gives life and takes it as it pleases. Here it exhibits its dual divinefunction, it is both wife and mother. The mankind's destiny is not only linked to the vagaries of time and weather changes. It also depends on the plant stratum which can be beneficial as it can be evil. This intrinsic connection between man and nature is the result of the diversity of plants that bear witness to a specific biotope allowing man to learn the essence of its knowledge and its mastery of the world. The relationship between man and nature is primarily a sacred one.

\section{General Method}

To carry out this research work, we relied on the use of data from archaeological, anthropological, ethno-cultural, mytho-critical studies we highlighted through a comparative approach based on elements of oral and literary texts: tales and novels. In fact, we had to collect oral stories through surveys of storyteller samples on the islands of Martinique, St. Lucie and Dominique. We also used the work of Elsie Clue Parsons [3] American anthropologist who collected all the Caribbean tales and their avatars. We have focused on the written tales that we identified in the Caribbean literature. The reading of fiction texts allowed us to target the presence of tales in the literary text and their influences on writing and aesthetics. Also, in addition to the work of archaeologists we conducted archaeological excavations at Dizac, (Diamant, Martinique) (Sainte-Luce, Martinique). They enabled us to read the symbols and myths inscribed on the adornos, the statues and the coil pottery. Using this as a starting point, we were able to target the faults of the analysis proposed by critics and focus our research on a new reading of the mythical narratives drawn from the observation of archaeological findings in order to understand the relationship between man and the environment.

\section{The Magical-Religious Power of Plants in the Caribbean Literature}

In a number of literary texts, the writers of the Caribbean highlight the intrinsic relationship between nature and the creole world. It is a dimension inherited from the slavery period and well before it from the link the Amerindian world maintained with nature. This relationship engenders a number of practices which qualify their followers as sorcerers or healers. We know about the anaesthetic power of certain plants such as curare [4] (Table 1), which, according to Amerindian practices allows you to catch a fish after you have drugged it. Les Nuits de Cachiri (The nights of the Cachiri) (Table 1) of René Jadfard, Guyanese novel published in the Caribbean in 1988, describes the travels of the European Pierre Doret and the many tribulations he faces through the Amazon 
Table 1. Plants representation table in Caribbean literature.

\begin{tabular}{|c|c|c|c|}
\hline $\begin{array}{l}\text { Plants and trees } \\
\text { found in the } \\
\text { Caribbean } \\
\text { literature } \\
\text { Popular names }\end{array}$ & $\begin{array}{c}\text { Scientific names } \\
\text { (Genus, species, families) }\end{array}$ & $\begin{array}{c}\text { Relevant literary texts or stories and } \\
\text { legends }\end{array}$ & $\begin{array}{l}\text { Characteristics, properties } \\
\text { and symbolism }\end{array}$ \\
\hline Kapok tree & $\begin{array}{l}\text { Ceibapentandra } \\
\text { (Bombacaceae) }\end{array}$ & $\begin{array}{l}\text { The nights of the Cachiri (A. Jadfard) } \\
\text { Tales of life and death (Ina Césaire) } \\
\text { Délice and the kapok tree (X. Orville) } \\
\text { I TitubaSalem witch (M. Condé) }\end{array}$ & $\begin{array}{l}\text { Symbol of power, father figure } \\
\text { force and resistance, symbol of death } \\
\text { and terror, identity symbol, protector } \\
\text { damnation of the soul, oracle, } \\
\text { keeper of history, } \\
\text { anthropo-morphism, knowledge }\end{array}$ \\
\hline $\begin{array}{l}\text { Acomat } \\
\text { (Akoma) }\end{array}$ & $\begin{array}{l}\text { Sideroxylon foetidissimum } \\
\text { (Sapotaceae) }\end{array}$ & ITituba Salem witch (M. Condé) & $\begin{array}{c}\text { Symbol of resistance } \\
\text { Symbol of the anchoring } \\
\text { Herculean strength }\end{array}$ \\
\hline Cachiri & $\begin{array}{l}\text { Manihot esculenta } \\
\text { (Euphorbiaceae) }\end{array}$ & The nights of the Cachiri (A. Jadfard) & $\begin{array}{c}\text { Clairvoyance } \\
\text { Oracle Function } \\
\text { Divinatory function }\end{array}$ \\
\hline Curare & $\begin{array}{l}\text { Strychnos toxifera } \\
\text { (Loganiaceae) }\end{array}$ & The nights of the Cachiri (A. Jadfard) & Intoxicating, anaesthetic \\
\hline Mapou & $\begin{array}{l}\text { Pisonia fragrens } \\
\quad \text { (Myrtaceae) }\end{array}$ & I Tituba Salem witch (M. Condé) & $\begin{array}{l}\text { Fear } \\
\text { Fright } \\
\text { Demons }\end{array}$ \\
\hline Jacaranda tree & $\begin{array}{c}\text { Delonix regia } \\
\text { (Caesalpiniaceae) }\end{array}$ & I Tituba Salem witch (M. Condé) & $\begin{array}{l}\text { Fear } \\
\text { Fright } \\
\text { Demons }\end{array}$ \\
\hline Calebassier & $\begin{array}{l}\text { Crescentia cujete } \\
\text { (Bignoniaceae) }\end{array}$ & I Tituba Salem witch (M. Condé) & $\begin{array}{l}\text { Fear } \\
\text { Fright } \\
\text { Demons }\end{array}$ \\
\hline Dagame & $\begin{array}{c}\text { Calycophyllum candidissimum } \\
\text { (Rubiaceae) }\end{array}$ & Why? (Lydia Cabrera) & $\begin{array}{l}\text { Fertility, paternity, Oracle, } \\
\text { divination function }\end{array}$ \\
\hline Cursed fig tree & Ficus citrifolia (Moraceae) & Masters of the dew (Jacques Roumain) & $\begin{array}{l}\text { Link between heaven and Earth, } \\
\text { regeneration, life guard, fertility }\end{array}$ \\
\hline $\begin{array}{l}\text { Blue flowered } \\
\text { Jacaranda tree }\end{array}$ & $\begin{array}{l}\text { Jacaranda mimosifolia } \\
\text { (Bignoniaceae) }\end{array}$ & $\begin{array}{c}\text { The blue-flowered Jacaranda tree } \\
\text { (J L. Baghio’O) }\end{array}$ & $\begin{array}{l}\text { Genesis, reading of history, identity, } \\
\text { freedom, resistance, renewal, } \\
\text { refoundation, divinity, Native } \\
\text { American heritage, cultural } \\
\text { polysynthetism }\end{array}$ \\
\hline Siguine & $\begin{array}{c}\text { Dieffenbachia seguine } \\
\text { (Araceae) }\end{array}$ & $\begin{array}{l}\text { A dish of pork with green bananas } \\
\text { (S. and A. Schwarz-Bart) }\end{array}$ & $\begin{array}{l}\text { Hallucination, evocation of } \\
\text { memories, recall of the } \\
\text { homeland, inner journey }\end{array}$ \\
\hline Bean (leaves) & Phaseolus vulgaris (Fabaceae) & Rue Cases-nègres (J. Zobel) & Magical-religious, healing \\
\hline Cabouya & Furcraea tuberosa (Agavaceae) & La Rue Cases-nègres (J. Zobel) & Magical-religious, healing \\
\hline Mauve & Malva sylvestris (Malvaceae) & Why? (Lydia Cabrera) & $\begin{array}{l}\text { Poison, Resistance, weapon of war } \\
\text { against colonists, revolution }\end{array}$ \\
\hline Manioc & $\begin{array}{l}\text { Manihot esculenta } \\
\text { (Euphorbiaceae) }\end{array}$ & Macunaíma (M de Andrade) & Magical power, strength and force \\
\hline
\end{tabular}

jungle. For this stranger who sees the world of the bush people and the Amerindians of the river and the forest for the first time, these civilizations allow him to discover an undeniable report of closeness and fusion between men and the natural world. If the latter may appear monstrous, ready at any moment to take away the life of its aggressors and human predators, it also dazzles the protagonist by its diversity and the virtues of the plants which can also be tree growing plants. 
The relationship of the forest man and nature is above all spiritual and sacred. Man gives plants absolute powers to the point of venerating them and praying to them every time before acting. The tree or plant is life. Each tree, each plant has its own language. The piaye or great sorcerer, a kind of shaman holds the power to decipher messages from plants and the powers they possess. Isn't the shaman the recipient of the clairvoyance and prediction powers conferred by beverages from mixtures of forest, garden orabates plants? We already see it when the old Commou having followed the shenanigans of young Makais to seduce Camayé's bride, Miyalou, intervenes to stop the seduction game. Doesn't he warn the young woman reminding her of the precepts that govern community life and the duty of the wife towards her husband by saying these words:

"Miyalou, beware! The Indian woman cannot forget what she owes her Tamouchi. Miyalou, remember that the eye of the Indian sees everything. Miyalou, remember that the Indian's anger is terrible." [4].

These admonitions are not without power and significance because they fall under a philosophy, a perception of a life and a culture that supports the idea of a symbiosis with nature. The tree which is at the same time source and guardian of life is invoked as witness, as it is the channel through which man comes into contact with the celestial sphere. It sometimes plays the role of a tutelary god because we should not forget that according to the native American legend, it is the tree that gives life to the woman. According to this legend, the woman, originally without sex, owes her fertility to the combined actions of the woodpecker and the tree. In fact, according to Antébi [5] "the Inriri bird's task was to sculpt the body of women tied to a tree, digging like in a wood beam in the place where usually the core of women can be found". Thus man must worship the tree to which it owes his life. In fact, after he reprimanded the woman, the piaye prays at the foot of a tree:

"He left without waiting for a reply; he was not asking. Walking up to a nearby kapok tree, he struck it three times with his forehead; three times he hit the ground with his heel mumbling unintelligible words." [4].

This image supplied to us by the narrator of the Nights of the Cachiri takes us back to a symbolic tree of the creole world: the kapok tree (Table 1). We find this symbol in a Martinique tale named "The sons of the ram" contained among other in the collection presented by Ina Césaire Conte de nuits et de jours aux Antilles (Tale of nights and days in the West Indies) [6]. The central character who requested to know his father faces a deadly struggle. To be victorious, he must train, acquire fighting techniques and especially show courage in front of his father. He can defeat the latter only after he manages to destroy his target, a kapok tree ${ }^{1}$ on which he trained. It is a very important symbol insofar as it bears witness to a centuries-old culture, it symbolizes strength and resistance. In this case this plant has a dual natureas in the collective unconscious it is synonymous with a majestic nature but also a diabolic one. It carries with it death and terror, it scares people. Maryse Condé gives us a perfect illustration in her novel I, Tituba... Black Witch of Salem. They hanged Tituba's mother on this tree after she resisted Darnell's rape and after she dealt him two knife blows. In a pathetic voice the narrator tells us:

"They hanged my mother.

I saw her body spinning in the lower branches of a kapok tree." [7]

But isn't the kapok tree also the protector of our lives? Tradition has it that when a child is born, we bury the placenta under a tree that foreshadows the totem which will accompany the child throughout its existence. We must take care not to cut it because it contains the identity of the relevant person in its bosom. The tree is considered his double in the social life. By tradition each child has a tree planted in a corner of the garden not far from the family home. It is its protector. The narrator tells us:

"He took me in his big bony hands and anointed my forehead with fresh blood from a chicken after burying my mother's placenta under a kapok tree. Then, holding me by the feet, he presented my body to the four corners of the horizon." [7]

We shouldn't be surprised by the dual nature of the most majestic of the Antilles tree: on one hand it exhibits an obvious supremacy which it shares with the acomat that Maryse Condé personifies comparing it with Yao's size from the point of view of its gigantic silhouette but it is also a plant linked to death and the damnation of the soul. Speaking of the acomat (Table 1), the narrator sees in it Herculean strength and a symbol of resistance that emerges through the silhouette of the hero, as a true anchoring figure. This is the portrait the narrator draws for us:

"Yao got up and his head touched the ceiling of the hut, for this Negro was as high as an acomat." [7].

Hitting the tree three times with his forehead then the ground three times with his heel, means that the piaye

${ }^{1}$ Tree with evil and magical virtues in principle housing evil spirits and witches. 
engages in a fierce fight against evil and thus confronts the demon of temptation to save the girl. It takes the kapok tree as witness and puts in its hands the fate of Makais on whom he puts an evil spell after warning and defeating him.

The lesson had no effect on the young man and it is the groom himself who shows the young man the dangers of his actions by using a parable. This gift of eloquence is given to him at the time when he is preparing to enjoy the benefits of the cachiri. This drink allows the people to build stronger ties, but also grants prophetic gifts to those who drink it. Therefore, in a very subtle way he announces the death of Makais without in fact threatening him and naming him. This prophecy will soon come true and the young man encounters danger after danger and being wounded, will turn to Commou who once more warns him of the dangers brought on by his recklessness:

"Your father is Tamouchi. You're his only son. Your heart is guilty and the destiny will punish you. Love is a ghost. When you see a woman's teeth, it is the devil who smiles. If you follow us one hour more, TamouchiMakais will not see his son again. He will find that Yolock has taken him forever. Makais, here's your paddle. Get in your Canoe without turning. Don't say goodbye to anyone and disappear." [4].

Once more, the old shaman speaks to a tree to exorcise the evil plaguing the young man and silently makes an incantatory prayer to expiate the fault.

"Commou examines the wound and the arrow. He pulls a knife from his vine belt, it stabs a tree three times, hits his chest and remains motionless, with unseeing eyes." [4].

The shaman's attitude and gestures are symbolic because beyond the mechanical gesture and physical confrontation with the tree, he gives it a divine dimension as well as an expiatory value. This dual nature of the tree in the Caribbean literature can be seen in some folktales because while revered, it plays the role of assistant to protect the hero and when it does not, it foreshadows the character of the devil. It is often a representation of a giant with large teeth, tutelary guardian with a formless mouth spewing divine or diabolical words, threats, omens. As described by Maryse Condé, it haunts the collective imagination at night, taking unusual shapes irrespective of its species and its family: this in the botanical sense! The mother of Tituba and Jennifer, the wife of the béké has dark memories of it. The narrator confesses that:

"After all, we were only two children frightened by the roar of large nocturnal animals and the theatre of the shadows of the jacaranda, calebassiers and mapous trees of the plantation." [7] (Table 1).

Note, however, that in all the stories, the tree is sturdy and it is the symbol of strength, it is mostly characterized by its huge size; it is now ready for all challenges. The tree is often personified and deified, it belongs to the pantheon of the gods or the sphere of demons. The principle of personification obliges the narrators to identify it with a plant character which is often referred to as the "father" or "dad". It is a secret being which embodies the ancestor or the guardian of the forest. It has powers which give it an undeniable influence over all the beings making up the ecosystem. In a story entitled "la montagne des troiscristalsd" or (the mountain of the three gold crystals) from the Caribbean folklore, Ina Césaire shows us a narrator who paints the portrait of an ancestral character, demiurge reigning over the forest and its surroundings. This is what the narrator tells us:

"Chérina galloped, galloped... At one point, Jasmine saw a huge white door framed by intertwined vines blocking their way. He dismounted and began to climb the vines. He climbed and climbed and with amazement saw that what he had taken for a door were the teeth of an old man, so large that they touched the ground. The vines were his beard! He told the old man: 'Hello, Father!' The man replied: 'Bouhouhou! Who is the sad individual who clings to my whiskers?' Jasmine then responded: 'Forgive me, Father! Would you be so kind as to tell me the way to the mountain of the three gold crystals?'” [6].

As we have seen earlier among American Indians, the tree is also symbol of life and fertility. It is driven by a twofold principle resembling the androgynous myth in Plato. It is a hermaphrodite in some stories. In fact, thanks to its sap, it seeds and gives life. Thus, in the tale of Lydia Cabrera, "The women pray to the Agame tree" [8] the Narrator describes the adventures of a young man who, victim of the jealousy of the men in his village, is ordered to cut down the Dagametree (Table 1) only to disappear forever. Unfortunately for these men, the teenager and the tree were one and the same and when he cut down the totem tree under duress, thousands of chips flew, they were female figures escaping from the sap which played the role of blood fluid, they were disseminated and impregnated all the girls in the village.

The open wound in the trunk gushes a stream of ruby coloured blood and from it a woman escapes and sheflees, fast like a ghost. 
While cutting, Bondo sang cheerfully, without a second of rest. With each axe blow, millions of chips were cut from the tree and each chip flew until it found the belly of a woman where to sink. And as many young and healthy women there were in the region, near or far, even in the most remote and distant place, without exception their womb received a chip of the precious tree, the tree of his life which Bondo the Desired was cutting down.

However, the one who had escaped from the Dagame in the blood caused by the first axe blow, appeared to Bondo's parents and revealed to them the betrayal their son was suffering that very day. She ran through the village showing herself to every woman and repeating in her ear in her small nasal voice with the remains of an uncomfortable accent of Spirits and Goblins:

-Moananketo, tu petit-mensu, yourBondo,.

There, in the wood is dying, Ah!

Chiquirindumha! Ah! Moana! Bondo

Mononoensambia, they are killing him!...

When they looked at her properly after the first shock passed, this unknown woman, although pleasant, had no feet. Her approach, just like icy dew, made the hair and skin wet. Finally someone saw her fade into the opening of a door, leaving a pleasant smell of sap and cut fresh branches.

Thus alerted, the women, crazy with pain, went to the wood, and they saw Bondo whostanding, gave the tree trunk one last axe blow. -Sangrimania!

The trunk collapsed and Bondo fell dead before their eyes; "Bondo the beloved, but he truly defeated death, since they were each carrying a chip of the precious wood and they were all carrying his descendants.” [8].

As we can see here, the tree not only plays a role in the balance of the ecological chain, but in addition it is the heart of the preservation of the human species of the ontological family. The founding or refounding myth works insofar as a part of the hero is found in each wood chip and each woman is fertilised by these chips. We also see this refounding myth in Jacques Roumain's famous novel Masters of the dew, when Manuel mates for the first time with Annaise at the foot of the cursed fig tree whose head reaches heaven [9] and whose legs sit in water [9]. Here, the forest not only appears in the eyes of the characters and the narrator as the bottom of the world [9], the beginning of life, this heavenly place where for the first time the first man and the first woman meet, itis associated with women (Annaise, the new Eve) fertilized by the man (Manual, modern Adam) as the cursed fig tree [9] (Table 1), this ancient tree of knowledge that penetrates her with its roots.

(He [Manuel] removed the vines and she [Annaise] entered the mystery of the cursed fig tree as he opened her kneesso she opened herself to him [9].

The relationship established here between man and nature is certainly that of a new alliance, where the sap, water and blood mingle to enter the womb of the woman as the bowels of the Earth, the tumult of new and resurgent life. The tree and the man find a kind of cosmic and ontological balance. In all the tales and all texts, paths open as the body of the woman, the evil trees are erased before the new life or in front of heroes carrying this penetrating light to lighten the darkness that dominates the forest and allowing the eaten bodies to be resurrected. This image counteracts that of large devouring forests seen in most tales and especially that of the virgin forest found in writers such as José Eustacio Rivera, in the Voragine or in Victor Hugo's Legend of the centuries. Let us remember these verses of the French poet who paints for us the image of the forest:

"The trees are all Jaws that eat

The elements, scattered in the soft living air.” [10].

The reading of the text focuses on the trees and plants in general in the collective imagination, showing us an ambivalence of this motive among Caribbean writers. However, let's look more closely at two totemic trees mentioned in a number of texts and which feed this poetic imagination, namely, the Jacaranda and the Kapok tree. At least two authors have explored this image: Xavier Orville and Jean-Louis Baghio’O.

\section{The Kapok Tree and the Blue-Flowered Jacaranda Tree: Two Symbols of Synthesis Writing}

In the novels of Xavier Orville Délice and the kapok tree (Table 1) and Jean-Louis Baghio’O, The blue flowered jacaranda tree (Table 1) the plant and animal stratum join forces and take shape human to carry out a number of rites or turn oracles to guide the hero in his wanderings. In the novel of Xavier Orville, the kapok tree drives the story from the start of the novel. Its importance is so great that it assumes the voice of the Narrator, mixing 
its own story to the one of the hero and the community of Blackbirds. It speaks in the first person, we could almost say homodiegetically.

This is the true voice of the creole storyteller who tells us the circumstances of its intervention in the heart of the vigil and the adventures of his trip before arriving at his destination:

"I went down river, bumping my canoe in the jumps, and all the Silk of the moons was not enough to soften my bruises nor the long scars on my forehead.

I descended the rapids, towering cliffs with salty scents: my ears still buzz with the water's noise." [11].

The tree undergoes a metamorphosis to take on human status, and as the master of the word, it tells its story for its listeners. The storyteller does the same in his introduction, the plant world is entrusted with the task to introduce the character of Délice. The narrator, witness to the events, wrote the history of the heroine as a wise old man who remembers both the places and the facts. Demiurge and omniscient, it takes the stage to tell the story, and invites us to accompany him on a long initiation journey to the heart of the collective memory and the primal self. As in Chamoiseau's Theold slave and the mastiff and in Carpentier's The lost steps [12], this journey is a quest for knowledge and self:

"A being/a tree, grand, majestic, full and rich of its knowledge of the world, a wise man, 'solar and rot-proof, here I stand. [...]' Me, the kapok tree, finally I am seen whole, you can still see on my feet the centuries-old dust of the roads." [11].

Raised to the rank of the divine, this character speaks with authority to reach the collective consciousness and does not let any obstacle hinder it. It knows its mission: its first task is to help the heroine, protect her and give her the testimony of buried memories. It speaks for the ancestors; it is the bridge between the earth and the heavenly world, it is he who opens or closes the door. Characterised by its anthropomorphic dimension in the narrative, it continuously takes us back to the wonderful world of Caribbean creole storytelling. The forest is the space of choice where the word is spoken and where the scene takes place. We are in the land of the Tree-God, at the heart of its Kingdom. Due to its giant size, although wonderful, it is also scary and dangerous; it is versatile, and dual: it carries motherhood as well as villainy. Lyricism and poetry are then mixed and under the eye of the reader they paint the features of a fabulous character. The kapok tree (the tree of knowledge), laid the foundations of an ethno-Genesis through its omniscient words:

"The sky is very sweet, my roots and the water increase my desire for Sun." [11].

Tree of the spoken word, it becomes a verb itself just like the storyteller who sits in the middle of the circle to speak the sacred word. As foreshadowed in the Amerindian legends trees and women merge in suffering to become one being. Seeing Délice's pain, the compassionate kapok tree becomes one with her: they merge.

"After the death of Laurent, I was myself victim or witness of a series of tragic events which more than ever fused my life with that of Délice." [11].

Witness of the sufferings of the young woman, it tells of the metamorphosis, the vegetalization of the person it had to protect:

"Since then, I have known the sweat of her brow, the salt of her tears, the dust on her hands, her feet crucified in pain and loneliness.

Pain and fatigue bend her a little more towards the Earth. Every day she loves the trees more, every day she feels she resembles them more: the weight of the sky on her shoulders and in her kidneys, the numbness of suffering, the chained roots, the bad weather of sadness, the wrinkles from the bark of time, the very low beat of the sap, the pulled branches and leaves, the stillness, the silence, the rain, the seasons, she feels them just like they do." [11].

This compassion leads the tree and the young woman to become one. The woman returns to her plant origins. She again finds her primal body starting a process of individuation, the tree is the symbol of one's own self:

"Each morning began again for centuries, the light always a little bit more dim.

Me, I was becoming increasingly evil. Then little by little, he saw the light in his mind and understood that her misfortune did not exist, that it was his own misfortune." [11].

In Baghio'O novel, the image of the blue-flowered Jacaranda tree [13], is another attempt to explain the Genesis telling us the saga of O'O. This image is woven through the entire novel that takes on the appearance of a tale and it runs through the story like a watermark in an epic atmosphere with a particular historical flavour. The tree is a genealogical symbol, it tells the story of a family just like Télumée tells the saga of the Lougandorfamily in Simone Schwarz-Bart's novel Rain and winds on Télumée-Miracle. The tree continues the interrupted story and restores the truth and the authenticity of the facts. Moreover, in the preface of the novel Maryse Condé 
says:

"It functioned as the emblematic sign of a historical continuum, of which the Caribbean Community has been aware for a long time, foreign as it was to itself, deprived of its word, dispossessed of its cultural treasures." [13].

Like Xavier Orville's kapok tree, the blue-flowered Jacaranda tree serves as a pretext for the Narrator to tell the story of the West Indies. Through metamorphosis it suggests the idea of ajoint cultural polysynthetism which gives birth to this new people. The Amazon rainforest is unequivocally invoked here, as the native substrate to which the African and European blood is added. The three circumstantial elements are gathered together to create this famous continuum Maryse Condé talked about and which we discussed in our thesis on the creole tales. This is what the Narrator tells us:

"To the general amazement of credible witnesses, this tree of Brazilian origin, within dented foliage with composed pennate structure, namely leaves inserted in two parallel rows, along an axis, like the mountain ash; the flower with a red and regular corolla, with free petals, a little like the clove, began to move, and then to shed its skin with a long sound of a thicket shuddering as if some inner beast had disturbed it; and turned a beautiful blue colour. The surprise was even greater when, at the same time, they saw the stubby, crushed tree as if bent towards itself, grouchy, with spreading or weeping branches, straighten, grow and reach towards the sky as if it has freed itself of a centuries-long hated burden.” [13].

The blue-flowered Jacaranda tree sends us back to the genesis of the Caribbean world and serves as a link between generations. The ancestral covenant is sealed again and the new covenant promises to live to the rhythm of a civilization emerged from this cultural and genetic hybridization. The tree symbolizes a trinity, Africa, America and Europe, which Glissant called the three kinds of migrants. There are those who were dispossessed of their land and who come from the deep Amazon, those who are deprived of speech and their gods, reduced to the most abject condition, and those who conquering the land plunged these quiet and prosperous lands into chaos. The blue-flowered Jacaranda tree witnesses this dramatic story and manages the feat of the meeting and the metamorphosis to give birth to a new being, bearer of hope and freedom. In this work of fiction mingling epic and history, the blue-flowered Jacaranda tree, symbolic character portrays the attitude of the wise observer, like the old Amerindian or African sorcerer who looks benevolently on his tribe. Two strong images contribute to the emergence of this double continuum in the literary text, namely: the Native American continuum and the continuum of the narrative discourse of the Creole tales, being understood that both are used to cement the poetry and the imagination. It is the image of the snake and fish that are both universals present also in the classical mythology. As proof we have the meeting of Délice with the trail-man, snake-man, coming straight from the Earth and who, like a phallus, become erect and mate with Délice. This is the image the kapok Narrator shows us:

"So the trail swells, stretches, leaps, pulls out of the ground, shudders, sticks to Délice’s skin.” [11]

In our two texts each writer gave an important place to the plant world, to two trees that influence the imaginary and the relationship with the world of the Caribbean. They are the kapok tree and the blue-flowered Jacaranda tree. However, at the heart of these motives we find beliefs derived from the Amerindian, European and African heritage and other cultures like India for example to enhance the cosmopolitan nature in the background of the stories. Here we recognize the influence of a wonderful universe and a baroque universe which give the narrative its specific flavour.

\section{From the Hallucinogenic Power of Plants to the Symbol of Resistance}

During this work of analysis on the symbolism of plants in literature we noticed that the writers' use of a pattern derived from the biotope and the different ecosystems has undeniable value since this is where the texts have their sources and therefore become anchored in the Caribbean world.

\subsection{The Plants' Hallucinogenic Power}

When we talk about Simone and André Schwarz-Bart's novel, Un plat de porc aux bananesvertes (A dish of pork with green bananas) we note that the narrator emphasizes the hallucinatory power of the plants of her country. It is due to this power that the Parisian hospital patient manages to escape from her prison-like universe to try to regain her identity and relive unforgettable moments with her ancestors. Like the cannabis causes visions which allow its user to travel, the siguine [14] (Table 1) used by the novel's protagonist allows her to iso- 
late herself and to contact her ancestors with whom she begins a dialogue. The absorption of this hallucinogenic plant gives her the power to leave her body and become introspective. During this flashback, the narrator invites us to go back in time through the maze of memory and to pluck the important moments of her history from her unconscious mind.

The consciousness is queried and during her madness the character starts adialogue with imaginary characters who at one time or another have entered her life. She finds herself facing her own self and her dialogue with her own people proves to be a real indictment where all accuse her of cowardice and of abandoning her family to try to find a better life elsewhere. This revelation results in the character's mental breakdown and a sense of guilt. The truth is hard to bear and the ingestion of this substance reveals the existence of a syndrome that takes the form of a split personality in the character. We can also say that the character engages in a disalienation treatment since the dream state caused by the siguine corresponds to exorcising the disease, a catharsis that allows her to survive a hellish situation and withstand prison life. Taking refuge in her past is for her a sort of therapy that allows her to go back to her roots and thus regain her Negro identity.

\subsection{Tropical Plants and Their Dual Life and Death Power}

In Simone and André Schwarz-Bart's work we saw one of the healing dimensions of plants through the example of the siguine, operating as a catalyst for the spirit and the primal being. This perspective plays on the ambivalence of the plants which have a dual life and death power. As for the plants with the potential to kill, we will refer to the poisonous plants found in Alejo Carpentier's novels which like the curare can kill instantly.

In this world's kingdom thenarratorpaints for us the revolt of the Saint-Domingueslaves which will give rise to the world famous Haitian Revolution. On the one hand, the narrator shows us the importance of the forest in the lives of men as it helps them to organise the resistance and revolution. It is in the heart of the forest that the Bois Caiman oath is written. In addition, the narrator tells us how the slaves organised their resistance by using their plant knowledge. They sow death by using the toxic properties of poisonous plants and mushrooms [15] by rubbing them against the snouts of livestock and poisoning the masters' daily use water.

\section{Two Examples of Anthropization in the Caribbean Literature and Their Implications for the Human Chain}

\subsection{The Damages of Anthropization in the Work of Jacques Roumain}

The work of Jacques Roumain, his famous novel Masters of the dew teaches usa great lesson in the failure to respect nature and the human intervention in the heart of the biotope. The novel begins with an exposure scene where man finds himself struggling with poverty and hunger. The narrator mentions the problem of deforestation as damage and an irreversible process, the men had abused the forest to indulge in malicious acts like for example cutting wood to make charcoal or burning the forest to obtain agricultural land.

The results of this persecution against nature can soon be seen since it is the entire ecological chain that suffers due to man's ingratitude. The narrator then shows us the devastating effects of uncontrolled human actions: desertification, rainfall scarcity, springs drying up, the sudden death of animals, the scarcity of food, human violence reflected by a fierce struggle for survival and the death of human beings. The picture the narrator paints for us in Masters of the dew is apocalyptic. The Earth's mantle is almost torn, thus offering no hope of life.

The situation can be reversed only when the main character, Manuel Jean-Joseph returns from Cuba to undertake a new quest for water and the rehabilitation of his fellow human beings. During this quest, it is the vegetation that will guide the novel's hero providing him with clues that will lead him to this splendid age-old tree with its roots in the deep flesh of the Earth. The cursed fig tree stands as guardian of the water source and of men's work, helping them to revive and regenerate the land.

\subsection{Positive Anthropization in the Novels of Joseph Zobel}

Unlike this negative action of appropriation of forest areas in Jacques Roumain's novel, Joseph Zobel's novel offers us a rather positive view of human action on arid areas such as Diamant. The project which feeds the eponymous character Diab'la [16] resulted in the appropriation of the land to fertilize it and propose to the population products likely to facilitate the survival of the human species. The character then engages in a quest by searching among mountains and valleys for the places best suited to establish what might be called a creole 
garden. The Narrator highlights the benefits of this action by listing the profusion of plants and fruits that allow the survival of men and women of the commune.

This action transformed the daily life of the Diamant people since the profusion of fruits and vegetables is accompanied by the herd's growth as well as its diversification. It shows how the ecological chain could prosper through a controlled and intelligent action. He tells us:

"The vegetables, fruit, coal, gave poultry, pigs, cabris, sheep which had young and could produce fillies, bulls, heifers, which could give them land, vegetables, fruit..." [16].

The clear results lead the character to extend his mastery of nature by diversifying his crops and creating terraces on the hills. The vision of Joseph Zobel is already part of a revolutionary program since without knowing it already, in 1946, the Martinique novelist just like Jacques Roumain plants the seeds of what one may later call sustainable and controlled development. The importance of this philosophical approach to the land and plants is more than symbolic because it shows us that between nature and man there is a true communion which we should maintain. The two novelists defend the idea of the love of nature, the land, plants and life. That's what Diab'la says:

"It was a very lively circle of work, expectation and joy.

Because what is needed to live: is a heart strong enough to meet any challenge, which knows the trees, the wind, the water, the sun and the men, there, in a good strong chest." [16].

\section{The Role of the Forest in Fairy Tales and the Literature of the Caribbean}

We must understand the structure of the tale and the different strata it contains, that the forest is experienced as a privileged space, a space of survival and organisation for the characters in the story. Similarly, is this space of survival (or environment) and organisation the symbol of a symbiosis and harmony between man and the real world? This will certainly lead to evoking the forest or wood space in its ecological dimension, as space of refoundation and equilibrium of the human and animal species in the story and a few times simply in the literature.

\subsection{The Tales and Literary Narratives: A Sedimentary and Layered Organisation}

The study of fairy tales and the literature of the Caribbean and the Americas, just like all the stories in general, suggests an organic strata structure and a hierarchy according to a specific order of things and nature. Therefore we see a human stratum, an animal stratum and a plant stratum.

\subsubsection{The Human Stratum}

This organic stratum shows us man and the place he had acquired in the ecological and economic system. It puts men in relationships and defines the ties that bind them. Inside this stratum, which is part of an ecological unit forming a system, the relationships between the social groups are built on principles of rivalry and conflict. The forest, space of life storage appears as the theatre of a ruthless confrontation between predators and victims. The human stratum which forms an integral part of the ecological system is marked by operators or biological markers that separate the groups into two broad categories: the strong and the weak. This biological and physical categorization, symbol of an antagonism which already highlights the ideological theme of the tales and storiesgives us an account of the existence of a conflict of interests and a political organization within the forest area and around this area. The human stratum is dependent on the natural world; it is obvious that the two worlds with divergent interests will compete with each other. The conflict that follows is clannish and the archetypes are described using the natural model: big, strong, robust, giant, small, puny, tiny and wizened, etc. We see a connotation of the force, the opulence, the full power and giant size embodied in the model of the ogre and the man-eating giant, carnivorous, while in contrast we see the sickly, exhausted peasant, the poor, the unfortunates struggling genetically to breed and to procreate. The human stratum suffers from distortions, imbalances and inequalities.

\subsubsection{Animal Stratum}

This organic layer, integrated in the natural world, plays a special role in the ecological system. This is Vladimir Propp's point of view, presented in his Morphology of the folktale [17], an assistant that contributes to the protection of the weak human nature. This stratum symbolizes beneficial power, efficiency, endurance. It assists the 
human character in his wanderings, accompanies him during his travels, making suggestions and offering solutions that enable him to cope with the most difficult situations. Some animals, such as the lion or the horse, some birds, like the eagle and the hummingbird, or even some insects like the ant and spider give their support to the hero and will supply their skills so he can succeed.

\subsubsection{The Plant Stratum}

The plant layer is by far the superior stratum. It is the one which structures the imagination of the storyteller, but also the entire frame of the narrative discourse. It already defines the area where the action takes place. It's the forest. The hero always crosses the great wood; he travels the forest world from one end to the other. A number of events will take place at the heart of the forest or above it. The plant species is often soughtout, it also plays the role of assistant or helper like the animal stratum. The forest plays its role thoroughly in the extent that spirits inhabit it, and it expresses itself through the trees which, like oracles populate the path of the hero and assist him as he deserves. Complex and mysterious, this layer ranks above all things. It covers and protects the weak (men or animals), against predators.

The forest is an impressive character which makes a strong impression due to its giant size and its virtues. It is sovereign and holder of the secret laws. It acquires a sacred dimension, and all this gives it the status of temple or centre of divine authority. Through the trees that make it up, this plant stratum can serve as an intermediary between the cosmos and Earth, it provides the link between the Earth and sky, between men and the gods. It is the spokesperson, messenger as well as oracle named the invisible and unpredictable. It dominates the human stratum and can offer its hospitality when it shows no hostility towards him or when it uses its virtues. Since it is characterised by its superiority and is seen in the imagination as a sacred space, as the substrate of the values and primal knowledge, it is interesting to see how this space occupies the unconscious and how the imagination conceives it to turn it into a protective regeneration matrix.

\subsection{The Forest, a Privileged Place of Survival and Organisation in the Tales and the Literature}

When the narrative alludes to the habitat of the hero, the Narrator describes the place as a space located at the edge of a forest. It is most often a simple hut in a clearing unlike the house where the master or the aggressor live. It took the character hours, days, months or even years to reach the house of the assailant to avenge his family and restore order. The forest is a place of survival, a space where we find all those who live outside the plantation, factory and fields system. Place of retreat and anchoring, the forest allows the characters in the story to organise and live in isolation, only to return to attack the house and loot the gardens and fields of important land owners who reign in terror over the region. Thus, some characters like Ti Jean, Ti Marie, Ti Zindien, TiAlbè, KonpèSèpan, KonpèKabrit, KonpèLapen, like to take refuge and hide when they are pursued by their enemies. In his narrative The old slave and the Mastiff [18], Patrick Chamoiseau paints us a great picture of the slave's flight to the depths of the forest. In the story of Ti Jean ${ }^{2}$ pursued by the devil, Ti Jean and Ti Marie take refuge in the heart of the forest where they hide. In a tale titled "Les chemins de l'île se fermaient et s'ouvraient" tiré du recueil de Lydia Cabrera, Pourquoi? "(The paths of the island closed and opened" drawn from Lydia Cabrera's collection of stories, Why?) [8], the men can no longer withstand the terror caused by the devil, take refuge in the forest where unfortunately they get lost. In the daily imagination the forest is a dangerous place, inhabited by evil spirits, devils, djinn, duens, evil geniuses and harmful and unhealthy animals. Thus, the forest is the symbol of death and danger. You must not enter it if you are not protected. This is why the characters who have not been elected and foreseen for a mission of redemption will never be able to return from the great wood which gobbles them up. Devils, female demons and other predatory spirits such as bats live there and take true pleasure in trapping humans who venture there to feed on their blood. The heroes must face many unexpected dangers. The old slave who escapes from the house in Patrick Chamoiseau's novel is in the grip of terror, his imagination wanders and the forest fills with ghost and spirits of all kinds, evil in any case:

"It sees shapes, troubled, troubling, threatening shapes. Impossible to identify. They come out of nothingness. They flock to him. They are here. They are over there. There are all sorts without model and type. And then, there are eyes without eyelids, dissipated in clouds where amniotic waves wait. And then mouths open like

\footnotetext{
${ }^{2}$ Collection of poems in verse from the Middle Ages, narrating the deeds of heroes or illustrious characters. In the creole tale, it is a set of stories recounting the achievements of a creole character.
} 
doorways without doors. And-then left hands braided under the influence of a language. And-then raised arms and musician's lips. There are nine waves ridden by terrors. And-then the suffering flesh that he seems to know?" [18].

Later, the old man ends up nose-to-nose with a snake in the heart of the forest, and the character is just as terrified.

"He hears a whistling sound. Then another. And then another, in the distance. He is petrified. The unnameable. The unnameable. He doesn't know if the deadly fangs are moving towards him, or if they come from the fevers of his spirit. He waits." [18].

However, as everything that exists and is part of the real world, the forest is also seen from a different angle, this time as beneficial. This is revealed through its ambivalence since, as it is likely to kill, it can also give life. When the hero of the story enters it, it is because he knows that the forest is a special place where he can find solutions to the problems of the social group, but also the healing of souls. Thus, in most stories, the narrator presents it as an ally of the heroes: it protects them and gives them good advice. In fact, in the story of Ti Jean, it is the forest which offers its hospitality to the brother and sister and protects them from their aggressor. In a tale named "Konkabritsesouchbwa", the forest intervenes to stop the aggressor in his progress. In Lydia Cabrera's tale, it is the spirit of the forest which addresses the twins to advise the man tells them of the remedy that will allow them to make the spirit of the terrifying ogre disappear for ever:

"Fetch three irons you find in the wood, a tuft of purple and a frying pan. Tears off itsheart, flay it, mix it with leaves and bury it after having put it in the pan." [8], (Table 1).

In addition to this protective dimension, in most stories the forest appears like a true nourishing mother. Thus, in his story entitled Macounaïma [19], Mario de Andrade paints for us scenes where the central character uses the gifts of the forest that brings him the food necessary for the well-being of the community. In fact, due to the famine which ravaged the village, the character went in the forest and due to its kindness was allowed to capture a tapir which could feed the tribe. The family refusing to believe his feat, he asked his sister-in-law Sofara to be his witness and bring back the proof of his catch. The narratorunveiling the virtues of the forest and its complicity with the hero says:

"She obeyed and returned telling everyone that truly he had snared a huge tapir which was already dead. The tribe went seeking the animal, each speculating on the intelligence of the boy. When Jigue arrived with his empty pineapple bodkin, he found the family trying to skin the game and lent a hand." [19].

Nurturing and protective mother, the forest appears as a magical and wonderful place. As the forces of evil act in the world, the forces of good respond to the concerns of the hero and take shape to protect him. This is the case of the orphan Fekue in a tale titled "La tortueportesamaison sur le dos, le maja Rampe et le lézards' accroche au mur" (The turtle carries his house on his back, the maja crawls and the lizard clings to the wall) [8]. In this tale, we see an orphan who, living on the charity of the people of his village, was accustomed to visit the forest. During his wanderings, the child used to offer a present to the trees and the plants he visited. One day he no longer had anything to offer, so he opened a vein and offered his blood to the forest creatures. Immediately, the master of the trees appeared and offered him a treasure. Back home, he understood the gift which had been offered to him. Unfortunately, the rumour spread that he had become rich and many were jealous of him to the point they set a trap to kill and rob him. One day when he ventured in the forest, his opponents ambushed him and were preparing to kill him when the cicada Cumandendecrippled them with his singing and the master of the Woods intervened to throw an evil spell on them. Since then, the turtle Jicotea was trapped for eternity of his body, the lizard was now forced to live plastered to walls and trees, and the maja lost his legs and was sentenced to crawl and to live under the threat of men and their machetes. The examples we have just cited demonstrate the relationship between men and the forest space. The forest appears as mysterious, as a feared and respected space because, according to the perception of the people who live close to it, it contains many magical virtues in its bosom. It is the place of mysticism and especially the temple of a number of beliefs as the tutelary gods live there. The forest is in fact a space of profusion, a dynamic place where good and bad spirits, good and bad creatures intermingle and manifest themselves. Thus, characters like $\mathrm{Iku}^{3}$ the man-eating devil, Courroupira the other ogre who wanted to eat Macounaïma during his trip in the forest, the black snake who suckled the breasts of $\mathrm{Ci}$ and whose venom was suckled by Macounaima's newborn, the beast with seven heads, are as many representations of the forces of evil living at the heart of the forest together with the protective ones such as

${ }^{3}$ IKU, diabolical character who haunts the forest in Lydia Cabrera’s tale, “The paths of the island closed and opened”. 
Osain-Ochacha-Queregueyo the great master of the woods and Orisha ${ }^{4}$ Kompè Kolibri the master-drum which according to the native American legend is the son of Iali, unrepentant traveller and messenger between heaven and Earth, KompèKabrit ${ }^{5}$ Kompè Lèg ${ }^{6}$, Annansithe spider, the ant, Kompè Lyon ${ }^{7}$, all bring comfort to the hero and support him in his quest.

\section{The Forest, a Symbiotic Space}

As we have just seen, the forest is a vibrant space where strange and singular characters live, like the duens and the djinns, the monsters and the beneficial and generous spirits. It is here that the forest acquires its venerable and sacred dimension. This force which characterizes it comes from its dual nature since it is defined as a mystical place where a fight between good and evil takes place. However, the reading of most of the stories led us to grasp the importance of this biotope in the lives of human beings and especially how it is perceived through their imagination. The fantastic tale and writings being the most appropriate media for translating the relationship the man has with his space and explain how he sees himself and how he represents his world, we are better able to understand the symbiosis that results from this relationship between man and his natural environment. The trees and forests are therefore part of a cultural dynamics in humans and condition their interdependence but mostly the way it sees his immediate surroundings. The forest is also the place of self-disclosure. It allows the human being to find its self and to reconsider its existence. In some native American legends, the forest and the trees are part of the design of the world, of the genesis and the relationship of human beings with the natural environment. Our research included the exploration of native American myths through observation of the signs on the sculptures and art objects of these peoples through our study of the archaeology in the Caribbean, it seemed important to interpret them in order to understand the relationship between man and his natural environment. The extensive research such as those carried out by Henri Petit-Jean-Roger or Elisabeth Antébi or Honnychurch Lennox paved our way and facilitated our interpretation of the symbols in the tale. Simply recall that at the beginning of the genesis of the Caribbean world, the Taïnonation was victim of an abduction, the women have been kidnapped, and the men came in the rain crying at the water's edge and complained about their new existence, telling the world of the lack they suffered. It is during the rain, and in the heart of the forest they came to see the spirits of their women float along the trees until the day where they entrust to Karakarakol ${ }^{8}$ the mission to retrieve their wives and bring them back within the tribe. Similarly, according to the native American myth, since the creation of the world, man finds himself alone and will have to find a mate to perpetuate the species. The tree is the symbol of rooting and the perpetuation of the species. The forest, considered the place of buried secrets and collective memory, knows to reveal its origins to him because it was the only one to preserve them jealously through time and history. It is indeed it who reveals the mineral, the existence of this Caribbean stone to the central character of Patrick Chamoiseau in The old slave and the Mastiff [18]. Thanks to the protective action of the forest, the stone may deliver its secrets to the being who starts to dream, his history and his humanity are then revealed:

"The stone dreams. It engulfs me in its dreams. I squeeze myself against it, with greedy hands. My mind loses its moorings. I might talk to it, I speak to a stone. Or dream with it. Yes, our dreams are intertwined, a knot of seas, savannas, large Islands and isles, attacks and wars, dark holds and migrant wanderings over a hundred thousand times a thousand years. A junction of exiles and gods, failures and conquests, slavery and death. All of this, grandiose call, swirls in a movement of life alive on this earth. The Earth. We are all the Earth." [18]

The forest in the psychical representation is also the place of mystical and magical practices. It feeds the beliefs and contains enough virtues to allow the man to acquire this supernatural power which will help him dominate the world and to exercise his powers inherited from the spirits and the gods. Thus, the forest is conducive to magical practices and ancestral rites. The visible and the invisible world share the same space naturally and there things can take body and forms, transform and morph. In contact with the forest, man transcends reality, he sublimates everything because he inherits superior powers unknown to the rest of the world thanks to the virtues of plants, herbs and leaves. This is the case of Macounaïma who, pursued by Courroupira was sprinkled

\footnotetext{
${ }^{4}$ Master of the sacred woods in Lydia Cabrera's tale.

${ }^{5}$ Companion Cabrit.

${ }^{6}$ Companion Eagle.

${ }^{7}$ Companion Lion.

${ }^{8}$ Karakarakol, legendary character of native American myths, Taïno with a mangy body and suckers whose mission was to bring back the women abducted by the Caribbean.
} 
with manioc juice [19] (Table 1) and was transformed into a strong and vigorous man. Another episode in Macounaïma' story makes us understand the virtues of the forest: the hero having eaten one of Courroupira's legs, he manages to get rid of the poisoned meat using the silty water of a puddle.

"Macounaïma arrived at the edge of a puddle, the Narrator tells us, he drank the silty water and vomited the meat." [19]

The forest becomes symbol of healing and regeneration. The man reaches perfect harmony with this biocenosis and its biotope; both agree and reach an agreement. There is a fusional relationship between man and nature. Having transcended the world and reality, he rises to become a spirit himself and communicates with the spirits of the forest. Once this spiritual contact is established, the human being can perform all the rites, he can transform, become invincible and especially reach this sacred dimension that makes him a feared and respected exceptional being.

\section{The Forest, a Space of Refounding and Balance}

If as we have seen, the forest appears as a place of magic and witchcraft, a space where black magic and white magic compete-for example we see the sorcerer Congo Sicongo-lun-debantua [8], incarnation of the devil, or Okurri Boroku [8] who reigned supreme over the Cuban forest, while beside them, we find Oloddumare, the master Obatala, Olorun, Chango Oshira and Olofi, the creator of life-in a fight where the light and the darkness oppose each other, this sacred space is also a place of initiation where young persons must acquire a number of skills and where they learn of virtue, courage and bravery. Fertility rituals allow the hero to forge his character and to fortify himself. René Jadfard, in his novel Les nuits de Cachiri (The nights of the Cachiri) [4] (Table 1), gives us a great example when he describes a nuptial rite in the Guyanese forest in which the future spouses must confront adversity and show that they are worthy and do honour to the village. The couple were abandoned to the manioc ants, locked in a hammock, the Narrator explains that:

"The ants are the common enemy, the adversity, the bad fate against which, together, the future spouses fight. Fierce, exciting, life-threatening struggle that must be completed without uttering a complaint which would only mean weakness. Camayé and Miyalou's couragehonors Commou, honors Couhan, honours the village. Camayé confirms his rank of Chief and Indian; Miyalou glowingly proves that she is truly fit to become his wife. Otherwise, the Tamouchi would not be considered a man. He would be denied, despised. Perhaps he would have to leave the tribe, Miyalou with him.” [4].

We find this initiation and training rite in a Martinique tale called Le fils $d u$ bélier (The son of the ram) contained among other in the collection presented by Ina Césaire Conte de nuits et de jours aux Antilles (Tale of nights and days in the Caribbean) [6]. The central character whorequested to know his father must confront him in a deadly fight. To do this, he must train, acquire fighting techniques and especially show courage against the monster. He can only defeat his progenitor after successfully destroying its target, a kapok tree (Table 1$)^{9}$ on which he trained in the forest, place of initiation and training by excellence. Apart from the fact that the forest is seen as a space of initiation and formation of character and human psychology, a place where one is forged, strengthened and tempered, it plays an important and symbolic role in the relationship of the human being with his vital space. It even functions as the foundation of his existence. It is the starting point of life and all narrative frames are forged or are built around the forest theme. The commonly used vocabulary constantly refers to it using terms such as "woods, large forest, forest, black forest, virgin forest, tree, papa tree, wood source, herbs, shrubbery, leaves, branches" which refer to the plant stratum in the narrative. The exploration of the forest myth in the tales and stories shows that it plays a very important role in the transformation and evolution of human beings. Most heroes and characters become more assured, grow and mature with their passage in the forest. The child leaves the silly age to join the adult world and carries out his social tasks. We see it with Macounaïma, with Ti Jean, with the Ibelles of Cuba, with Camayé and many other characters. In his analysis of fairy tales, Bruno Bettelheim highlights the evolution of teenagers and the symbolism of the forest in the learning process as well as its significance at the level of the individual and collective unconscious. Speaking of the behaviour of the adolescent in full puberty and the symbolism of fairy tales, the psycho-critic says:

"In real life as in fairy tales, he tries to assert his young masculinity (or femininity), by often going through dangerous adventures. Through his symbolic language the fairy tale establishes that after gathering his forces in solitude, the young person must become himself. In fact, this evolution is full of dangers: the teenager must

\footnotetext{
${ }^{9}$ Tree with evil and magical virtues which is in principle the home of evil spirits and witches.
} 
turn his back on the security of childhood (he is lost in a forest full of dangers); He must learn to face the anxieties and the violent tendencies of others (he meets wild beasts and dragons); He must learn to know himself (he encountersstrange characters and experiences). Through this process, the young person loses his former innocence: he is no longer the "Simple one" regarded as a stupid and obscure being, or his or her mother's little boy or girl." [20]

The forest is by definition a sanctuary for various people and particularly the Celts, Greeks, Hindus, Buddhists $^{10}$ and Japanese ${ }^{11}$. In the Dictionary of symbols, we read the following:

"The forests are soft, reads the Dhammapada, a place where the world does not enter; the saint finds his rest there." [21]

The forest is often associated with the mountain, and as such, it is part of the personification process, participating in the sacred and divine process as seen by the popular imagination as the hair of the latter (the mountain) and thereby it becomes a symbol of power. It (the forest) participates in the ecological and cosmogonic balance since it allows the mountain to stop the clouds, bring rain and of course participate in the heavenly benefits. This is how Yu-le-Grand in Chinese mythology decided to cut down the trees in order to attack the mountains or Tsin Che Housangti started reprisals against Mount Kiang by felling the trees after being wounded during a thunderstorm.

This shows how much these characters had failed to establish a link with the ecology of this area, while other people consider the tree a symbol of life, an intermediary between the heaven and the Earth where it plunges its roots. The ridge of trees compared to their hair is supposed to touch the heavenly vault and the tree thereby facilitates the communication between our world and the world of the gods. The tree plays this important role in ancient Gaul before the Roman conquest. Similarly, in the Amerindian civilization closer to us, the tree plays a very important role since it allows the spirits to communicate with the earth world. In some folktales the tree is venerated, it gives good advice to the hero or it prefigures the character of the devil. It is often represented as a giant with large teeth, with a misshapen mouth spewing divine or diabolical words, threats, omens; It is robust and ready for all challenges. This plant character is often named "father" or "dad". It embodies the ancestor or the guardian of the forest. In any case it has powers which give it a certain ascendancy throughout the forest and over all those who live there or live near the forest space. In a tale called La montagne des troiscristalsd' or (The mountain of the three gold crystals), drawn from folklore and collected by Ina Césaire, the narrator gives us a portrait of the ancestral character and demiurge ruling over the forest and its surroundings. This is what the narrator tells us:

"Chérina galloped, galloped... At one point, Jasmine saw a huge white door framed by intertwined vines blocking their way. He dismounted and began to climb the vines. He climbed and climbed and with amazement saw that what he had taken for a door were the teeth of an old man, so large that they touched the ground. The vines were his beard! He told the old man: 'Hello, Father!' The man replied: 'Bouhouhou! Who is the sad individual who clings to my whiskers? Jasmine then responded: 'Forgive me, Father! Would you be so kind as to tell me the way to the mountain of the three gold crystals?"” [6].

This analysis clearly shows us the place the forest occupies in the daily life of the population, in the genesis of the communities and in the training of individuals. We understand better how the imaginary affects the forest world and how it defines the people's relationship with this biocenosis. The forest is not a world apart, it has joined the economic system as much as the other's way of thinking. It is part of the real world but also acts on the identity and cultural values of the community. Sometimes personified, therefore assuming anthropological or anthropomorphic features, sometimes deified, sometimes sacred, it straddles the secular and the religious worlds. Thus, it is defined by a kind of duality which makes it a place of death and life, a space where the demons (devils and saints) intertwine to reveal to the human beings their human nature, that is, their weaknesses and their strengths.

The approach of the forests' image in the literature and tales of the Americas and the Caribbean leads us to an ontogeny and to understanding how the human being evolves in its environment. Nothing is innocent because as Bruno Bettelheim put it so well, the tales give us in-depth knowledge of the unconscious, the forest is sometimes the symbol of fears which are often ancestral or of moral values embedded in the collective unconscious. The

\footnotetext{
${ }^{10}$ See the symbolism of the forest of Brocéliande with the Celts or the forest of Dodona among the Greeks. Similarly, in India, the forest is a place of withdrawal for the sannyasa and Buddhist ascetes.

${ }^{11}$ We know that in Japan, the Toril is very significant since it prefigures the entrance of a temple estate and that the latter is in most cases nothing more than a conifer tree forest.
} 
ethnologists, ethnolinguists, anthropologists, ethnobotanists and literary critics who focus on the question of orality in this region of the world, on the place of tales in the process of the formation of human beings, on the foundations of the imagination in the process of creation and on the relationship between men and their natural environments in their practices and their attempts to decrypt the anthropological, sociological and cultural reality in their work of clearing the indigenous thought, like Freud suggests in his analysis of Jensen's Gradiva [22], play the role of a true archaeologist of the psyche to enable us to reach a new understanding of the man of these regions and therefore, of all human beings. As the image of the forest connects us to our age-old fears, it also brings healing to the soul and sometimes liberates us from our frustration and our repressed desires. To do this, it naturally accesses the imagination, stories, tales and literature, but it also lives in our proverbs to warn us against imprudence and our too unreasonable follies. We finish by understanding that this proverb pulled out of the forest myth and saying that "who wants to enter a large forest should not fear slipping on snails" represents a fundamental lesson referring to the dangers of forests worldwide. This lesson in caution is aimed at those who want to learn about life, and they must take in its fullest scope; they must understand that their life path can be full of pitfalls and traps of all kinds. Here, we are once more forced to note the analogy between life and the forest, and conclude that it is still a hyperbola which refers us to a generic value of the forest symbol. At the end of this analysis we see that the forest participates in the foundation or refoundation principle. It necessarily takes on a mythical value as defined by Yves Chevrel and Camille Dumoulié in a preface to the "Essays in honour of Pierre Brunel" in a collective work titled The myth in literature [23] where the co-authors state:

"Today for us the myth is mainly literary, or more generously artistic. Its word, which has become almost silent in this world abandoned by the gods Michel Butor evokes, however continues to take form in the body of the literary text or, for example, in the frame of film writing. But it is, first and foremost, the word 'myth' itself which has experienced a new guise in modern times. The promotion of 'literature' as absolute and a genre encompassing all other genres by the romantics of athenaeum, is accompanied by a genuine literary myth 'invention'. The distinction between fable and myth, as well as the revival of the latter term corresponded in the works of Herder, Hölderlin or Novalis, to a desire to find, beyond any allegorical interpretation, the true reality of the mythical figures, or even the sense of the sacred." [23].

\section{Conclusions}

The forest myth that runs through all of literary works, legends and tales, projection of a collective thought and vision, reveals itself as a permanent sign which the reader or interlocutor must decode even as it feeds the text or artistic project with his full vitality to give it the essence of its substance. The forest myth meets a requirement to give meaning, to propose an identification project to the collective unconscious. By the same token, here it finds its creative function through the release of the speech, anxieties and existential questions. Better yet, this myth found its relevance and usefulness at a time when we lose our values and milestones, and where the human beings need new beliefs to bear the existential vacuum plaguing the modern world. Like the other myths here it finds its purpose since it serves as a remedy to reveal the real world and the mysteries surrounding the latter. The myth shows us our own image and the depth of our soul, starting a quest for the truth and sometimes even a lack from which we suffer. Chamoiseau and de Glissant [24] show us this truth in their approach to refoundation or the various narrative texts we had to study through the questions of the quest and historical truth. The myth of the forest as a symbol helps us to understand how the world is perceived by the people who live there or who live near this space, since Luc Benoist [25] in an article titled "The world of symbols" leaves us with the following thoughts:

"Our knowledge of the world has followed the exploration that our sensitivity applied to the universe with which it was trying to identify. This analogy that ancient traditions established between the microcosm and the macrocosm represent the true key of figurative symbolism which uses nature's elements to express the concepts of the mind. This is why the spiritual world is reflected in the mirror of visible things in reverse images." [25].

This appropriation of the forest, of the symbol and the myth that it represents certainly allows us to demystify the unknown, to penetrate the infernal and discover a new space so we can meet another part of ourselves, (here arises the question of otherness) until we discover the monstrosity hidden deep in our unconscious, and simply address this definition of the human being.

\section{References}

[1] Zobel, J. (1974) The Black Shack Alley. Presence Africaine, Paris. 
[2] Jean-Georges, C. (1990) Creole Tales in the Caribbean Region, to a Ethnopédagogique Approach Dissertation New Regime. University of Paris IV, Sorbonne Paris, Paris.

[3] Parsons, E.C. (1933-1943) Folk-Lore of the Caribbean. In English and French, 3 vols.

[4] Rene, J. (1988) Nights Cachiri. Caribbean, Paris.

[5] Antebi, E. (1978) Ciboneys, Arawak and Carib. In: Chu, Ed., Arawak Review (Cultural Treasures of the Creole World), Paris.

[6] Césaire, I. (1948) Tales of Nights and Days in the Caribbean. Caribbean, Paris.

[7] Condé, M. (1986) Moi, Tituba... In: Witch, Ed., Mercure de France, Paris.

[8] Cabrera, L. (1954) Why? Gallimard, col. The Southern Cross, Paris.

[9] Romanian, J. (2003) Collected Works. Critical Edition, Agence Universitaire de la Francophonie, col. Archivos, Paris.

[10] Hugo, V. (1859) The Legend of Centuries. Hetzel Edition, Volume 2.

[11] Orville, X. (1977) Delight and Cheese. Grasset, Paris.

[12] Carpentier, A. (2009) The Lost Steps. Akal.

[13] Jean-Louis, B. (1980) The Blazing Blue Flowers. Mayenne, Caribbean.

[14] Schwarz-Bart, A. and Simone (2015) A Pork Dish with Green Bananas. Seuil, Paris.

[15] Carpentier, A. (1967) El Reinodeestemundo. Primera Edición (Segunda de la obra) of the Compañía General de Ediciones, S. A. Mexico.

[16] Zobel, J. (1946) Diab’la. New Latin Editions, Paris.

[17] Propp, V. (1970) Morphology of the Tale. Threshold Col. Point, Paris.

[18] Chamoiseau, P. (1997) The Slave and the Mastiff Old Man. Gallimard, Paris.

[19] De Andrade, M. (1997) Macounaïma or the Hero without any Character. Flammarion, Stock/Unesco/ ALLCAXX, Paris.

[20] Bettelheim, B. (1976) The Uses of Enchantment. APA Monitor, 7, 6-7. http://dx.doi.org/10.1037/e309842005-008

[21] Müller, M. and Fausböll, M. (1881) The Dhammapada and the Sutta Nipata. Sacred Books of the East, Vol. 10.

[22] Sigmund, F. (1949) Delusions and “Dreams in Gadiva”. Jensen, Gallimard, Paris.

[23] Chevrel, Y. and Camille, D. (2000) in The Myth in Literature, Essays in honor of Pierre Brunel. PUF, Paris.

[24] Glissant, E. (1996) Introduction to the Various Poetic. Gallimard, Paris.

[25] Benoist, L. (1975) Signs, Symbols and Myths What Do I know? No. 1605, 5th Edition, 26th Mile, the Second Quarter of 1981, PUF, Paris.

\section{Warmly welcome your paper submission to OALib Journal!}

- Publication on a daily basis

- 9 subject areas of science, technology and medicine

- Fair and rigorous peer-review system

- Fast publication process

- Article promotion in various social networking sites (LinkedIn, Facebook, Twitter, etc.)

- Widely-targeted and multidisciplinary audience to read your research

Submit Your Paper Online: Click Here to Submit

Contact Us: service@oalib.com 